\title{
SACROILITIS IN LEPROSY PATIENT EVOLVING TO A TYPICAL CONDITION OF AXIAL SPONDYLOARTHRITIS - A CHALLENGING DIAGNOSIS
}

Ana Carla Fernandes Oliveira (Hospital Universitário Lauro Wanderley - UFPB, JOAO PESSOA, PB, Brasil), Fernanda Tavares de Melo Cavalcanti (Hospital Universitário Lauro Wanderley, João Pessoa, PB, Brasil), Maria Roberta Melo Pereira Soares (Hospital Universitário Lauro Wanderley - UFPB, João Pessoa, PB, Brasil), Alessandra Sousa Braz (Hospital Universitário Lauro Wanderley - UFPB, João Pessoa, PB, Brasil), Eutilia Andrade Medeiros Freire (Hospital Universitário Lauro Wanderley - UFPB, João Pessoa, PB, Brasil)

\section{BACKGROUND}

Leprosy is a chronic granulomatous infection caused by Mycobacterium leprae that usually affects skin and nerves. The joints are the third most common site of involvement of the disease and can be the primary complaint. Joint manifestations have a variable prevalence depending on studies and geographical area. The clinical picture may mimic chronic arthritis such as rheumatoid arthritis and spondyloarthritis, although sacroiliac involvement is uncommon.

\section{CASE REPORT}

Male, 42 years old, driver, presented insidious pain in lumbar spine for about 2 years, one hour-long morning stiffness, worsening at rest and improving with activity. He also reported pain in the shoulders, with limited abduction. Antecedent of leprosy, with first symptoms started in 2016, along with those of low back pain. He received polychemotherapy from October 2016 to October 2017. Since then, he has developed pain and paresthesias in the forearm medial aspect and right hand, later diagnosed as leprosy neuritis (type 1 reaction). In tapered use of prednisone for the treatment of neuropathy. The persistence of inflammatory low back pain motivated the investigation of spondyloarthritis. Physical examination: rectification of lumbar lordosis, in addition to flexo-extension pain, without limitations, positive FABER test in left sacroiliac. Main exams: skin histopathology (09/26/16) with histiocytic, granulomatous infiltrate in superficial dermis, epithelioid cells, granulomas with lymphocytic exudation and inflammatory involvement of adnexal structures and nervous fillet, suggesting multibacilar leprosy diagnosis. Electroneuromyography (05/30/18): signs of compressive median nerve polyneuropathy to the left, signs of axonal polyneuropathy; Magnetic Resonance Imaging of the sacroiliac joints (11/12/18): bone marrow edema in the inferior subcortical aspect of the left iliac, fat deposition in the bone marrow in sacral articular surfaces, discrete bone cortical thickening in the sacroiliac joint edges. The patient was prescribed celecoxib and presented good response.

\section{CONCLUSION}

The joint involvement of leprosy remains underdiagnosed in our country, although we live in an endemic area to the disease. Rheumatologic manifestations may be the first symptom, leading to errors and delay in diagnosis and treatment. Anamnesis and detailed physical examination, considering epidemiology and clinical signs, such as spots with reduced sensitivity, raise the suspicion for the differential diagnosis of $\mathrm{M}$. leprae infection when evaluating a patient with chronic low back pain. 